\title{
HAK DAN AKTIVITAS POLITIK WANITA PERSPEKTIF ABŪ AL-A'LĀ AL-MAUDŪDĪ
}

\author{
Putri Adelia ${ }^{1}$ \\ ${ }^{1}$ Universitas Islam Negeri Sunan Kalijaga Yogyakarta \\ Sleman, Yogyakarta, Indonesia \\ putriadelia785@gmail.com
}

\begin{abstract}
Abstrak:
Dalam kehidupan sosial peran perempuan dibatasi pada wilayah domestik saja. Implikasinya perempuan tidak diperkenankan untuk mengambil peran di ranah publik, seperti berpendidikan yang setara dengan laki-laki, bekerja di luar rumah, bahkan ikut mengambil wilayah politik. Salah satu sarjana muslim era modern yang menafsirkan ayat itu sebagai batasan terhadap wanita untuk keluar rumah adalah Abū al-A 'lā al-Maudūdì. Penulis tertarik untuk menelisik lebih lanjut penafsirannya karena digolongkan ke dalam mufassir modern tetapi beberapa penafsiran terkait perempuan terkesan bias gender. Tulisan ini akan memabahas penafsiran al-Maudūdī mengenai QS. Al-Ahzab: 33 ayat ini dikatakan sebagai pijakan awal terkait persepsi pembatasan gerak perempuan di ranah publik yang dihasilkan dari pemahaman dari hasil interpretasi perintah untuk wanita agar selalu menetap di rumah. Kemudian menelisik bagaimana penafsirannya tersebut mempengaruhi aktifitas politik perempuan.
\end{abstract}

Kata kunci: Abū al-A 'la al-Maudūdì, politik, perempuan

\begin{abstract}
:
There is an assumption that develops in society that according to religion women have no place in social life and women's role is limited only in the domestic sphere. The implication is that women are not allowed to take roles in the public sphere, such as being educated as equals to men, working outside the home, even taking part in political territory. One of the modern-day Muslim scholars who interpreted the verse as a limitation on women leaving the house was Abü al-A 'là al-Maudūdī. The author is interested in further examining his interpretation because it is classified into modern commentators but some interpretations related to women seem to be gender biased. This paper will discuss al-Maudūdī's interpretation of the QS. Al-Ahzāb: 33 this verse is said to be the initial foothold regarding perceptions of restrictions on the movement of women in the public sphere resulting from an understanding of the results of the interpretation of orders for women to always remain at home. Then examine how this interpretation affects women's political activities.
\end{abstract}

Keywords: Abū al-A 'lā al-Maudūdī, politics, women 


\section{Pendahuluan}

Al-Qur'an merupakan sumber hukum utama dalam Islam. Selain itu, alQur'an berisi berbagai legislasi dan ajaran-ajaran moral. Hal ini dikarenakan AlQur'an, secara pragmatis, menggambarkan kejadian-kejadian pada masa Nabi. Sehingga, al-Qur'an tidak dapat terlepas dari praktik sosial pada masa itu.

Menilik sejarah di wilayah Arabia pada abad ke-7, Al-Qur'an tampak mengamati kondisi laki-laki yang saat itu menikmati otoritasnya atas perempuan dalam bidang politik, sosial, budaya dan keagamaan. Dalam hal ini Al-Qur'an menyatakan bahwa laki-laki bertanggung jawab atas perempuan dalam berbagai bidang dan wanita dibatasi geraknya. Pengamatan tersebut tersebut, oleh AlQur'an, tampak alamiah atau wajar bagi masyarakat Islam generasi awal dan sejalan dengan konteks sosial budaya mereka pada saat itu. ${ }^{1}$ Bila diamati secara sepintas saja tanpa melalui penelitian secara seksama, perempuan sepanjang peradaban hanya memainkan peran-peran sosial yang sempit, tidak seluas lakilaki.

Sementara peran domestik perempuan yang lebih menonjol ialah sebagai istri dan ibu rumah tangga. ${ }^{2}$ Hal tersebut dikarenakan beragamnya tafsiran atas ayat tentang perempuan, salah satunya adalah mengenai hak perempuan untuk keluar dari rumah. Sebagian masyarakat berasumsi bahwa dalam agamapun peran perempuan mendapatkan batasan dalam ranah sosial, sehingga ia hidup hanya di wilayah domestik saja. ${ }^{3}$ Implikasinya adalah para peempuan tidak diperkenankan untuk mengambil peran di ranah publik, seperti berpendidikan yang setara dengan laki-laki, bekerja di luar rumah, bahkan ikut mengambil bagian dalam wilayah politik.

Al-Qur'an merupakan sumber hukum utama dalam agama Islam, yang dijadikan legitimasi akan larangan wanita untuk keluar rumah adalah yang QS. Al-Aḥzāb: $33 .{ }^{4}$ Bagi ulama pra modern, ayat seperti itu mungkin tidak

${ }^{1}$ Abdullah Saeed, Reading the Quran in the Twenty First Century :A Contextualist Approach (New York : Routledge, 2014).

${ }^{2}$ Huzaemah Tahido Yanggo, "Pandangan Islam tentang Gender," dalam Mansur Fikih (ed), Membincang Feminisme Diskursus Gender Perspektif Islam (Surabaya : Risalah Gusti, 1996), 151

${ }^{3}$ Lajnah Pentashihan Mushaf Al-Qur'an, Kedudukan dan Peran Perempuan (Jakarta : Penerbit Aku Bisa, 2012), 76.

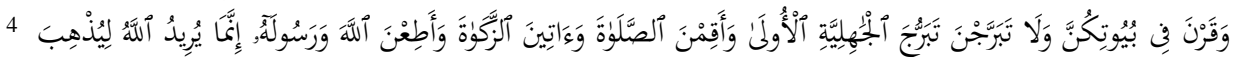

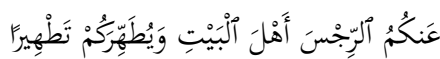

"dan hendaklah kamu tetap di rumahmu dan janganlah kamu berhias dan bertingkah laku seperti orang-orang Jahiliyah yang dahulu dan dirikanlah shalat, tunaikanlah zakat dan taatilah Allah dan Rasul-Nya. Sesungguhnya Allah bermaksud hendak 
dipertimbangkan lagi norma dan nilai yang ada dalam lingkungan turunya wahyu pada saat itu sebagai pedoman penafsiran. Mereka menafsirkan ayat tersebut sebagai aturan umum yang secara universal dapat dipraktikkan. ${ }^{5}$

Salah satu sarjana muslim era modern yang menafsirkan ayat itu sebagai batasan terhadap wanita untuk keluar rumah ialah Abū al-A'lā al-Maudūdī. Seorang pemikir muslim kontemporer yang banyak melahirkan karya-karya yang berpengaruh pada saat itu dan pendapat-pendapatnya diperhitungkan dalam dunia Islam.

Al-Maudūdī juga seorang cendekiawan yang memiliki fokus pada persoalan peradaban Islam, mulai dari politik, negara, dan sebagainya. ${ }^{6}$ Misalnya, al-Maudūdī berpandangan jika tujuan berdirinya negara Islam ialah terciptanya satu negara yang di dalamnya ideologi Islam diterapkan secara utuh di semua aspek kehidupan. ${ }^{7}$

Tulisan ini akan memabahas penafsiran al-Maudūdī mengenai QS. AlAhyzāb : 33 karena ayat ini bisa dikatakan sebagai pijakan awal terkait persepsi dibatasinya gerak permpuan di ranah publik yang dihasilkan dari pemahaman dari hasil interpretasi perintah untuk wanita agar selalu menetap di rumah. Pemikiran al-Maudūdī menjadi fokus kajian pada tulisan ini karena sebagai pemikir muslim kontemporer pendapatnya cukup berpenagruh pada zamannya. Ia juga dikenal sebagai tokoh fundamentalisme yang menganggap gerakan feminisme sebagai ancaman terhadap ideologi patriarkhi.

\section{Biografi Intelektual Abū al-A'lā al-Maudūdī}

Abū al-A'lā al-Maudūdī, lahir pada tahun 1903 di Aurangabad, India dan wafat di New York pada tahun 1979. ${ }^{8}$ Nama Abul A'la pernah menjadi kontroversi di antara pemikir lainnya pada zaman itu, disebabkan oleh "Abū alA 'lā" memiliki makna ayah dari Yang Maha Tinggi. Dan "Yang Maha Tinggi" merupakan kalimat yang dinisbatkan kepada Tuhan. Namun ia melakukan pembelaan diri, al-Maudūdī menggunakan beberapa ayat yang terdapat kata AlA'la dan Al-A'launa yang diperuntukkan kepada manusia, yakni Nabi Musa As,

menghilangkan dosa dari kamu, hai ahlul bait dan membersihkan kamu sebersihbersihnya."

${ }^{5}$ Abdullah Saeed, Reading the Quran in the Twenty First Century :A Contextualist Approach.

${ }^{6}$ Siti Nur Aisyah Mohd Azemi Azman, dan Sarinah Yahya, "Membangun Peradaban Islam Menurut al-Qur'an: Penelitian Surah al-Kahfi," Malaysian Journal of Social Sciences and Humanities 4, no. 7 (2019): 179.

${ }^{7}$ Syafri Gunawan, "Karakteristik Negara Islam: Kajian Awal Ide Negara Abul A'la Maudūdī," Jurnal al-Maqasid 5, no. 2 (2019): 187.

${ }^{8}$ Shodiq Abdullah, Pemikiran Abu al-A'la Maudūdī tentang Pendidikan Islam (Yogyakarta: Pustaka Pelajar, 1999), 233-234. 
dan orang beriman. Ia adalah keturunan Maudūd (seorang perawi hadis Rasulullah). Al-Maudūdī merupakan tokoh pembaharu dalam Islam. ${ }^{9}$

Al-Maudūdī belajar kepada ayahnya sendiri dan juga belajar di sekolah formal yang menyatukan model pendidikan Islam tradisional dengan model pendidikan modern di Barat. Selanjutnya, ia menempuh pendidikan di suatu universitas di Hydrabad. Tak lama setelah itu, ayahnya wafat, hal itu menyebabkan ia berhenti dari seklah formal. Akan tetapi ia belajar dengan cara otodidak di luar lembaga formal dan akhirnya mampu memahami bahasa Urdu, Arab, Inggris dan Persia. ${ }^{10}$

Karir al-Maudūdī ditorehkan sejak berusia 15, yakni sebagai wartawan. Iaa diangkat menjadi editor surat kabar berbahasa Urdu pada tahun 1920. Selain itu, ia aktif dalam dunia jurnalis,e dan sempat menjadi editor di beberapa media cetak India yang menjadi salah satu media cetak yang sangat berpengaruh pada masa 1920 -an. ${ }^{11}$

Selain seorang jurnalis, al-Maudūdī dikenal sebagai filsuf politik dan teolog Sunni di Pakistan dengan garis besar pemikirannya ortodoks abad ke 20. Al-Maudūdī juga banyak menulis buku. Karyanya yang hampir ratusan telah diterbitkan dalam berbagai media cetak. Ia termasuk pemikir muslim yang tidak mempunyai kajian khusus. Karya-karyanya yang multidisiplin itu antara lain berkaitan dengan politik, agama, sosial, budaya, pendidikan dan banyak lagi.beberapa karya al-Maudūd̄̄ antara lain adalah:

a. Tafhīm al-Qur'ān, ialah buah pikir yang monumental dari al-Maudūdī di bidang tafsir. Karyanya ini berisi tentang terjemahan dan penjelasan alMaudūdī atas ayat al-Qur'an. Kitab ini ditulis dalam bahasa Urdu, tetapi telah diterjemahkan ke bahasa Arab dan Inggris.

b. Al-Jihād fì al-Islām, berisi tentang pemahaman al-Maudūdī tentang pandangan Islam mengenai kekerasan dan perang.

c. Ușūl al-Asāsiyah Li Fahm Al-Qur'ān, berisi tentang dasar-dasar dan pokok-pokok dalam memahami Al-Qur'an

d. Al-Khilafah wa al-Malakiyah, berisi tentang gagasan-gagasan alMaudūdī tentang ke-khilafah-an dan kenegaraan.

e. Manhāj Jadīd at-Tarbiyah wa at-Ta'lìm, berisi tentang buah pikir alMaudūdī yang berkenaan dengan pembaharuan pendidikan Islam.

\footnotetext{
${ }^{9}$ Munawir Sjadzali, Islam dan Tata Negara : Ajaran dan Pemikiran (Jakarta : UI Press, 1990), 158.

10 Abū al-A'lā al-Maudūdī, Khilafah dan Kerajaan: Evaluasi Kritis Atas Sejarah Pemerintahan Islam (Bandung : Mizan, 1996), 7.

${ }^{11}$ Muhammad Iqbal dan Amin Husein Nasution, Pemikiran Politik Islam dari Masa Klasik Hingga Indonesia Kontemporer (Jakarta: Kencana, 2010), 172.
} 
f. Risālah Dīniyat, karya ini berisi tentang pengantar studi Islam yang diterjemahkan dalam bahasa Inggris sebagai Towards Understanding Islam.

\section{Penafsiran al-Maudūdī terhadap QS. Al-Aḥzāb : 33}

Al-Maudūdī banyak menulis tafsir dengan metode mauḍu' $i$ atau tematik, di antaranya adalah al-Riba fì al-Qur'ān dan al-Khilāfah wa al-Mulk. Adapun al-Maudūdī lengkap menafsirkan Al-Qur'an dari awal hingga akhir surat yaitu kitab Tafhìm al-Qur'ān yang berbahasa Urdu. Kitab tafsirnya yang berbahasa Urdu tersebut tidak bisa didapatkan secara utuh, tetapi penulis menemukan beberapa potong surat yang diterjemahkan dalam bahasa Arab, yaitu dalam surat an-Nur dan Al-Aḥzāb. Kitab tafsir Tafhìm Al-Qur'ān juga diterjemahkan ke dalam bahasa lain yaitu bahasa Inggris. ${ }^{12}$ Muqaddimah juga sudah diterjemahkan dalam bahasa Indonesia. dengan judul Pedoman Dasar untuk Memahami Al-Qur'an yang juga merupakan bagian dari Tafhìm al-Qur'ān. ${ }^{13}$

Mengenai penafsiran ayat ini, ayat tersebut bermaksud untuk mengesankan bahwa lingkungan aktivitas wanita yang sesungguhnya adalah rumahnya; ia harus menjalankan fungsinya di dalam lingkup itu dengan damai, dan ia harus keluar dari rumah hanya jika ada kebutuhan yang darurat.

Al-Maudūdī juga dengan tegas menyatakan ayat ini mengindikasikan bahwa Al-Qur'an dengan jelas tidak mengizinkan perempuan untuk mengejar kegiatan sosial yang berada di luar rumah, bekerja di kantor berdampingan dengan laki-laki, mendapatkan pendidikan bersama anak laki-laki di perguruan tinggi, menjadi perawat dan merawat laki-laki di dalam bangsal rumah sakit, berkerja sebagai pramugari atau dikirim ke luar negeri untuk kepentingan pendidikan atau pelatihan. ${ }^{14}$

Al-Maudūdī melanjutkan bahwa argumen-argumen yang dipakai para pendukung pendapat pembolehan perempuan untuk keluar dari rumah itu tidak tepat, di mana mereka menjadikan peristiwa ikut sertanya 'Āisyah, istri Nabi, dalam perang jamal. Al-Maudūdī menyangkal pendapat tersebut dengan argumen bahwa 'Abd Allāh bin Aḥmad bin Hanbal telah mencantumkan dalam Zawā'id al-Zuhd dan Ibn Munḍīr, Ibn Abī Șaibah dan Ibn Sa'd dalam bukubuku mereka tradisi dari Masruq, bahwa ketika 'Āisyah ra. membaca Al-Qur'an dan sampai pada ayat ini (wa qarna fi buyūtikunna), dia akan mulai menangis tanpa sadar; sedemikian rupa sehingga pembungkus kepalanya menjadi basah,

\footnotetext{
${ }^{12}$ Lihat english version dari kitab tafsir Tafhīm Al-Qur'ān di www.englishtafsir.com

${ }^{13}$ Abū al-A'lā al-Maudūd̄̄, Pedoman Dasar untuk Memahami Al-Qur'an (Jakarta : Gunung Jati, 1984), iv.

${ }^{14}$ Abū al-A'lā al-Maudūdī, Tafsīr Surah Al-Aḥāa (Tafhim Al-Qur'an), terj. Ahmad Idris (Mesir: t.p, 1976), 39.
} 
karena ini mengingatkannya pada kesalahan yang telah dilakukannya dalam Pertempuran Unta.

Argumennya ia perkuat melalui penjelasan ayat berikutnya yaitu "dan janganlah kamu berhias dan bertingkah laku seperti orang-orang Jahiliyah yang dahulu," menurut al-Maudūdī, memiliki dua komponen kata yang penting yang harus dipahami untuk bisa memahami keseluruhan ayat, yaitu term tabarruj dan jahiliyyah al-'üla. Kata tabarruj dalam ayat ini menurut alMaudūdī jika digunakan atau disandarkan kepada seorang wanita akan memiliki tiga makna. Pertama, ketika seorang wanita itu menunjukkan pesona wajah dan tubuhnya di hadapan orang-orang. Kedua, memakai atau memajang hiasan pakaian dan ornamen-ornamennya di hadapan orang lain. Ketiga, membuat dirinya mencolok dengan gaya berjalan dan gerakannya. ${ }^{15}$

Penjelasan tersebut serupa dengan apa yang disampaikan oleh para ahli tafsir dan ahli bahasa terkemuka seperti Mujahid, Qatadah dan Ibn Abī Nujaih yang mengatakan bahwa tabarruj berarti berjalan dengan cara yang sia-sia, memikat, dan genit. Sedangkan Muqātil mengatakan bahwa tabarruj berarti seorang wanita memajang cincin dan kalung di dadanya. Ia menambahkan pendapat al-Mubarrad bahwa tabarruj bermakna seorang wanita yang menampakkan perhiasan yang harusnya dia sembunyikan. Sedang Abū 'Ubaidah berkomentar maksud dari kata tersebut adalah seorang wanita yang membuat dirinya mencolok dengan memperlihatkan tubuhnya dan pakaiannya untuk menarik perhatian pria. ${ }^{16}$

Menurut al-Maudūdī jahiliyyah dalam terminologi Islam adalah setiap perilaku yang bertentangan dengan budaya dan peradaban Islam serta moralitas dan etika Islam serta cara berpikir dan perilaku Islam. ${ }^{17}$ Lebih lanjut ia menyatakan bahwa penjelasan-penjelasan tersebut semakin memperkuat pendapatnya bahwa Allah melarang wanita untuk keluar dari rumah mereka apalagi dengan memamerkan pesona fisik dan kecantikan mereka. Tuhan menginstruksikan mereka untuk tinggal di rumah mereka karena bidang aktivitas mereka yang sebenarnya adalah rumah mereka dan bukan dunia di luar. Perbuatan tersebut, menurutnya merupakan perbuatan orang-orang jahiliyah, tidak dibenarkan dalam Islam dan tidak bermanfaat ${ }^{18}$

${ }^{15}$ Abū al-A'lā al-Maudūdī, Tafsīr Surah Al-Aḥzāb (Tafhim Al-Qur'an), terj. Ahmad Idris, 40 .

${ }^{16}$ Abū al-A'lā al-Maudūdī, Tafsīr Surah Al-Aḥzāb (Tafhim Al-Qur'an), terj. Ahmad Idris, 40

${ }^{17}$ Abū al-A'lā al-Maudūdī, Tafsīr Surah Al-Aḥzāb (Tafhim Al-Qur'an), terj. Ahmad Idriss, 41

18 Abū al-A'lā al-Maudūdī, Tafsīr Surah Al-Aḥzāb (Tafhim Al-Qur'an), terj. Ahmad Idris, 41 
Pendapat al-Maudūdī ini tidak senada dengan sarjana muslim semasanya seperti Sayyid Quṭub. Dalam tafsirnya ia menyatakan bahwa ayat ini berisi bahwa rumahtangga merupakan tugas utama seorang perempuan (istri), padaahal tidak seperti itu. ${ }^{19}$ Meskipun Sayyid Quțub dan al-Maudūdī keduanya adalah pemikir muslim kontemporer dan pemikiran Sayyid Quțub pun dalam bidang-bidang tertentu pun banyak dipegaruhi oleh al-Maudūdī, tetapi pandangan mereka mengenai hal ini cenderung berbeda.

Quraish Shihab juga cenderung mengutip pendapat dari Sayyid Quṭub yang menyatakan perempuan di awal Islam melakukan banyak aktifitas yang memang dituntut untuk melakukan itu, seperti bekerja. Lebih lanjut, Quraish Shihab menjelaskan bahwa Islam tidak mendukung para perempuan untuk bekerja di ranah publik, namun jika pekerjaan tersebut dipandang perlu maka perempuan dibebaskan melakukan. ${ }^{20}$

Perbedaan para ulama dalam menafsirkan ayat tersebut adalah terkait makna kebahasaan dari kata wa qarna, yang kedua adalah memohon izin untuk keluar dari rumah karena keadaan darurat. Pertanyaannya adalah apa batasan dari yang dinamakan darurat tersebut. Pandangan yang sedikit berbeda adalah misalnya bahwa redaksi dalam tafsirannya adalah ayat "waqarna" yang diperuntukkan bagi istri Nabi saja, bukan untuk perempuan secara umum, sebab sudah ditegaskan dalam ayat sebelumnya, perempuan pada umumnya berbeda dengan istri Nabi, sehingga bentuk-bentuk larangan dan perintah di ayat selanjutnya ditujukan hanya untuk istri Nabi.

Namun al-Maudūdī menekankan kepada perempuan bahwa wilayahnya hanya berada didalam rumah dan perempuan dibatasi dari aktifitas publik, dengan alasan agar perempuan selalu dirumah sebagai wujud rasa hormat dan tenang, sehingga para perempuan dapat menyelesaikan tugas rumahtangganya. Jika mereka (perempuan) hendak bepergian, mereka diperbolehkan namun dengan persyaratan memeperhatikan kebersihan (suci) mereka dan memperhatikan rasa malu. ${ }^{21}$

\section{Perempuan dan Aktivitas Politik dalam Pandangan Al-Maudūdī}

Secara filososfis Al-Qur'an sebaiknya dibaca sesuai fakta yang ada. ${ }^{22}$ Fakta kejadian saat ayat diwahyukan yang jelas tidak sama dengan saat ini. Hal

${ }^{19}$ Sayyid Quṭub, Tafsīr F̄̄ Zilāli al-Qur'ān, Jilid VIII (Beirut :Dar al-Arabiyyah. t.th.),

7.

${ }^{20}$ M. Quraish Shihab, Tafsir al-Misbah, jilid 11 (Jakarta: Lentera Hati, 2017), 267.

${ }^{21}$ Abū al-A'lā al-Maudūdī, al-Hijab dan Status Wanita Dalam Islam, terj. Ahmad Noer Z (Bandung: Pustaka, t.t).

22 Muhsin Mahfudz, "Implikasi Pemahaman Tafsir Al-Qur'an Terhadap Sikap Keberagamaan," Tafsere 4, no. 2 (2016): 387. 
ini dilakukan agar secara tekstual al-Qur'an tetap hidup disegala zaman. Interpretasi terhadap teks-teks agama merupakan suatu mekanisme yang sangat penting. Interpretasi sejatinya menghasilkan makna teks yang menuntut pengungkapan mana melalui analisis berbagai level konteks. ${ }^{23}$

Tafsir sebagai salah satu komponen dalam kajian al-Qur'an dirasa tidak banyak menyentuh persoalan sosial kontemporer akibat masih dominannya aspek agama di dalamnya. Padahal, tafsir merupakan tugas intelektual yang tidak kenal henti untuk memberikan pemaknaan terhadap al-Qur'an. Dalam konteks modern, banyak persoalan sosial yang belum tersentuh, sehingga diperlukan keseriusan dan keberanian dalam mengembangkan tafsir sebagai metodologi interpretasi dengan elemen kearifan lokal. Beberapa kasus ketetapan hukum di Indonesia menunjukkan bahwa upaya pembumian tafsir dalam konteks kehidupan menjadi suatu keniscayaan. ${ }^{24}$

Al-Maudūdī, dengan berpijak pada ayat tersebut secara tidak langsung mempengaruhi cara pandangnya dalam hal aktivitas politik bagi perempuan. AlMaudūdī kokoh membuat batasaan untuk perempuan, apalagi mengenai dunia politik.

Bagi Maudūdī, ada empat syarat menjadi kepala negara, yakni laki-laki, Muslim, berakal dan dewasa, berasal dari negara Islam. ${ }^{25}$ Islam sangat memperhatikan secara fungsional terhadap peran manusia berdaarkan jenis kelamin. Bahwa pemerintahan merupakan hak dan tanggungjawa seorang lakilaki, dengan memasukkan perempuan diranah pemerintahan maka akan telah menyalahi ajaran Islam. ${ }^{26}$

Namun bersama partai Jamā'ah Islam, Maudūdī menonjolkan sikap moderat pada saat ada perempuan (Fatimma Jinnah) menjadi calon presiden dan menyeru untuk memberi dukungan kepadanya dan Maudūdī membersamai setiap kampanyenya. ${ }^{27}$

Di sisi lain, Maudūdī sempat mengubah program partai saat Perempuan Liga Muslim sering melancarkan protes. Pendapatnya terkait pertisipasi perempuan dalam dunia politik ialah dengan dirumuskannya "parlemen khusus" dengan beranggotakan perempuan secara keseluruhan. Selain itu, ia mengadakan divisi khusus dipartainya, yang diisi oleh perempuan dengan

${ }^{23}$ Nașr Hamid Abū Zaid, Al-Nașs, al-Sulțan, al-Haqīqah, terj. Sunarwoto Dema (Yogyakarta : LkiS, 2003), 111.

${ }^{24}$ Muhammad Nur Kholis Setiawan, Tafsir Sebagai Resepsi Al-Qur'an: Ke Arah Pemahaman Kitab Suci dalam Konteks Keindonesiaan (t.k. t.p., 2015), 5.

${ }^{25}$ Abu al-A'la al-Maudūdī, Sistem Politik Islam, terj. Asep Hikmat (Bandung : Mizan, 1998), 267.

${ }^{26}$ Abu al-A'la al-Maudūdī, Sistem Politik Islam, terj. Asep Hikmat, 268.

${ }^{27}$ Munawwir Sjadzali, Islam dan Tata Negara (Jakarta: UI Press, 1990), 174. 
ditugaskan seperti menjadi dewan penasehat presiden dalam hal legislatif, menduduki parlemen baik skala nasional maupun provinsi.

\section{Kesimpulan}

Sebagai pemikir muslim kontemporer, al-Maudūdī termasuk salah satu pengusung ideologi patriarkhi yang menginginkan laki-laki sebagai pusat penguasa atau pemegang kekuasaan dan perempuan sebagai yang dipimpin. Sikap inkonsisten Maudūdī sangat jelas dalam hal pembatasan peran dan fungsi perempuan di dunia politik. Namun, pada akhirnya ia berubah pandangan setelah terjadi proses lobying antara partai Jamā'ah Islam dengan partai Liga Islam Pakistan yakni berakhir dengan diberikannya dukungan kepada Fatimah Jinnah sebagai calon presiden.

\section{Daftar Pustaka}

Abdullah, Shodiq. Pemikiran Abū al-A 'lā Maudūd̄̄ tentang Pendidikan Islam. Yogyakarta: Pustaka Pelajar, 1999.

Azman, Siti Nur Āisyah Mohd Azemi, dan Sarinah Yahya. "Membangun Peradaban Islam Menurut al-Qur'an: Penelitian Surah al-Kahfi." Malaysian Journal of Social Sciences and Humanities 4, no. 7 (2019).

Gunawan, Syafri. "Karakteristik Negara Islam: Kajian Awal Ide Negara Abul A'la Maudūdī." Jurnal al-Maqasid 5, no. 2 (2019).

Iqbal, Muhammad dan Amin Husein Nasution. Pemikiran Politik Islam dari Masa Klasik Hingga Indonesia Kontemporer. Jakarta: Kencana, 2010.

Lajnah Pentashihan Mushaf Al-Qur'an. Kedudukan dan Peran Perempuan. Jakarta: Penerbit Aku Bisa, 2012.

Mahfudz, Muhsin. "Implikasi Pemahaman Tafsir Al-Qur'an Terhadap Sikap Keberagamaan." Tafsere 4, no. 2 (2016).

Al-Maudūd̄̄, Abū al-A'lā. Pedoman Dasar untuk Memahami Al-Qur'an. Jakarta: Gunung Jati, 1984.

Al-Maudūd̄̄, Abū al-A'lā. Khilafah dan Kerajaan: Evaluasi Kritis Atas Sejarah Pemerintahan Islam. Bandung: Mizan, 1996.

Al-Maudūdī, Abū al-A'lā. Sistem Politik Islam, terj. Asep Hikmat. Bandung: Mizan, 1998.

Saeed, Abdullah. Reading the Quran in the Twenty First Century: A Contextualist Approach. New York: Routledge, 2014.

Setiawan, Muhammad Nur Kholis. Tafsir Sebagai Resepsi Al-Qur'an: Ke Arah Pemahaman Kitab Suci dalam Konteks Keindonesiaan. t.k: t.p, t.t.

Shihab, M. Quraish. Tafsir al-Misbah. Jakarta: Lentera Hati, 2017.

Sjadzali, Munawir. Islam dan Tata Negara: Ajaran dan Pemikiran. Jakarta : UI Press, 1990.

Quțub, Sayyid. Tafsīr F̌̄ Zilāli Al-Qur'ān. Beirut: Dar al-Arabiyyah, t.t. 
Zaid, Nașr Hamid Abū. Al-Nașs, al-Sulțan, al-Haqīqah, terj. Sunarwoto Dema. Yogyakarta: LkiS, 2003. 